\title{
PENGARUH STRATEGI PEMBELAJARAN DAN KEMANDIRIAN SISWA TERHADAP HASIL BELAJAR PENDIDIKAN AGAMA ISLAM
}

\author{
Syaifullah ${ }^{1}$, Harun Sitompul ${ }^{2}$, Mukhtar $^{3}$ \\ ${ }^{1}$ Sekolah Menengah Atas Negeri 2 Takengon, Aceh Tengah, \\ ${ }^{2,3}$ Pascasarjana Universitas Negeri Medan \\ syaifullahhamid@yahoo.com
}

\begin{abstract}
Abstrak: Penelitian ini bertujuan untuk: (1) mengetahui hasil belajar Pendidikan Agama Islam siswa yang diajar dengan strategi pembelajaran portofolio lebih tinggi dari siswa yang diajar dengan strategi pembelajaran ekspositori. (2) mengetahui hasil belajar Pendidikan Agama Islam siswa yang memiliki Kemandirian Tinggi Dan kemandirian rendah. (3) mengetahui interaksi antara strategi pembelajaran dengan kemandirian terhadap hasil belajar Pendidikan Agama Islam. Penelitian ini dilaksanakan di SMA Negeri 2 Takengon Kabupaten Aceh Tengah. Populasi berjumlah 207 orang. Pengambilan sampel dilakukan dengan cluster random sampling berjumlah 55 orang yang terdiri dari kelas A.1 dan A.2. Metode penelitian yang digunakan adalah kuasi eksperimen dengan desain faktorial $2 \times 2$. Uji statistik yang digunakan adalah statistik deskriptif untuk menyajikan data dan dilanjutkan dengan statistik inferensial dengan menggunakan ANAVA dua jalur dengan taraf signifikan $\alpha=0,05$ yang dilanjutkan dengan uji Scheffe. Sebelumnya dilakukan uji analisis berupa uji normalitas dan uji homogenitas. Hasil penelitian menunjukan: (1) hasil belajar Pendidikan Agama Islam siswa yang diajarkan dengan strategi pembelajaran portofolio lebih tinggi dari pada hasil belajar siswa yang diajarkan dengan strategi pembelajaran ekspositori; (2) hasil belajar Pendidikan Agama Islam siswa yang memiliki kemandirian tinggi dari pada hasil belajar Pendidikan Agama Islam siswa yang memiliki kemandirian rendah; (3) terdapat interaksi antara strategi pembelajaran dengan kemandirian dalam mempengaruhi hasil belajar siswa.
\end{abstract}

Kata Kunci: portopolio, ekspositori, kemandirian, agama islam

\begin{abstract}
This study aims to: (1) find out the learning outcomes of Islamic Religious Education students who are taught with portfolio learning strategies are higher than students who are taught with expository learning strategies. (2) knowing the learning outcomes of Islamic Religious Education students who have High Independence and Low Independence. (3) find out the interaction between learning strategies and independence of learning outcomes of Islamic Religious Education. This research was conducted at SMA Negeri 2 Takengon, Central Aceh District. The population is 207 people. Sampling was done by cluster random sampling totaling 55 people consisting of classes A.1 and A.2. The research method used was a quasi-experimental with $2 \times 2$ factorial design. The statistical test used was descriptive statistics to present data and continued with inferential statistics using two-way ANOVA with a significant level $\alpha=0.05$ followed by the Scheffe test. Previously conducted an analysis test in the form of a normality test and a homogeneity test. The results showed: (1) the learning outcomes of Islamic Religious Education students who were taught with portfolio learning strategies were higher than the learning outcomes of students who were taught with expository learning strategies; (2) learning outcomes of Islamic Religious Education students who have high independence than the learning outcomes of Islamic Religious Education students who have low independence; (3) there is an interaction between learning strategies and independence in influencing student learning outcomes.
\end{abstract}

Keywords: portfolio, expository, independence, Islamic religion

\section{PENDAHULUAN}

Dalam suatu lembaga pendidikan, prestasi belajar merupakan indikator yang penting untuk mengukur keberhasilan proses belajar mengajar. Akan tetapi tidak bisa dipungkiri bahwa tinggi rendahnya prestasi siswa banyak dipengaruhi oleh faktor-faktor lain disamping proses pengajaran itu sendiri. Kemandirian dirumuskan sebagai suatu proses yang menentukan tingkatan kegiatan serta arah khusus dari tingkah laku manusia, yang merupakan kemandirian diri dalam mencapai sesuatu, Kemandirian adalah kondisi siswa yang mendorong untuk melakukan sesuatu tanpa adanya paksaan dari siapapun, jadi Kemandirian adalah belajar yang timbul dari keinginan sendiri tanpa adanya pengaruh dari orang lain yang mendorong seseorang untuk belajar, sehingga hasil belajar dapat meningkat. 
Didalam pengelolaan pengajaran, kemandirian belajar seseorang merupakan suatu masalah penting. Seorang siswa perlu memiliki sikap mandiri yang memperkuat dirinya sendiri untuk selalu terbiasa dan mempertinggi daya kendali diri. Sikap mandiri yang timbul dari kesadarannya sendiri akan dapat lebih memacu dan tahan lama dibandingkan dengan kemandirian yang timbul karena adanya pengawasan dari orang lain.

Beberapa hal yang menyebabkan rendahnya peranan dan efektifitas Pendidikan Agama Islam PAI dalam membentuk perserta didik yang beriman dan bertaqwa kepada Allah serta berakhlak mulia adalah : Pendidikan Agama Islam selama ini dilaksanakan menggunakan pendekatan pembelajaran yang kurang sesuai dengan tujuan yang hendak dicapai, Materi pembelajaran PAI yang lebih banyak bersifat teori, antara unsur Alqur'an keimanan, akhlak, fiqh, dan sejarah yang disajikan pada materi pembelajaran sendirisendiri, kurang berkaitan dengan mata pelajaran yang lain, model pembelajaran yang konvensional lebih menekankan pada pengayaan pengetahuan (kognitif pada tingkat yang rendah) dan pada pembentukan sikap (afektif) serta pembiasaan (Fsiko-motorik).

Semua variabel tersebut memiliki ketergantungan satu sama lain dan tidak dapat berdiri sendiri dalam keberhasilan siswa. Belum mengembirakan hasil belajar siswa diduga karena proses pembelajaran kurang mendukung pemahaman siswa yaitu, terlalu banyak hafalan, kurang dilengkapi dengan praktekpraktek di lapangan. Sebagaimana diungkapkan Wardiman (2001) bahwa strategi belajar kurang mendukung, mungkin tidak sesuai dengan materi yang diajarkan, mungkin terlalu monoton atau kurang bervariasi yang dapat menyebabkan belum maksimalnya prolehan hasil belajar.

Dalam rangka mengatasi persoalan perolehan hasil belajar mata pelajaran PAI yang masih relatif rendah, berbagai upaya dilakukan untuk meningkatkan kemampuan pemahaman siswa pada mata pelajaran PAI. Salah satu upaya yang dapat dilakukan adalah meningkatkan kualitas pembelajaran dengan penerapan pendekatan pembelajaran yang lebih baik.

\section{Hakikat Hasil Belajar Pendidikan Agama Islam}

Untuk memahami tentang konsep belajar di sini akan diawali dengan mengemukakan beberapa definisi tentang belajar di antaranya adalah : Cronbach, Harold Spears dan Geoch (Sardiman A.M, 2005) sebagai berikut: (1) Cronbach memberikan definisi: "Learning is shown by a change in behavior as a result of experience". "Belajar adalah memperlihatkan perubahan dalam perilaku sebagai hasil dari pengalaman", (2) Harold Spears memberikan batasan: "Learning is to observe, to read, to initiate, to try something themselves, to listen, to follow direction". "Belajar adalah mengamati, membaca, berinisiasi, mencoba sesuatu sendiri, mendengarkan, mengikuti petunjuk arahan, (3) Geoch, mengatakan: "Learning is a change in performance as a result of practice". "Belajar adalah perubahan dalam penampilan sebagai hasil praktek".

Pengertian belajar juga dikemukakan oleh Slameto (2003) yakni belajar adalah suatu proses usaha yang dilakukan seseorang untuk memperoleh suatu perubahan tingkah laku yang baru secara keseluruhan, sebagai hasil pengalamannya sendiri dalam interaksi dengan lingkungannya.

Gagne (1977) menyatakan bahwa belajar merupakan kegiatan yang komplek, hasil belajar merupakan kapabilitas. Setelah seseorang belajar maka ia akan memiliki pengetahuan, keterampilan dan sikap. Pengetahuan menunjuk pada imformasi yang tersimpan dalam pikiran, sedangkan keterampilan adalah suatu tindakan atau tingkah laku yang mampu diperlihatkan seseorang sebagai tanda bahwa orang tersebut telah belajar. Selanjutnya sikap adalah kemampuan seseorang menerima atau menolak obyek berdasarkan penilaian terhadap obyek tersebut.

Romizowski (1981) menyatakan bahwa hasil belajar diperoleh dalam bentuk pengetahuan dan keterampilan. Pengetahuan dikelompokkan pada empat katagori yaitu, (1) fakta, merupakan pengetahuan tentang objek nyata, hubungan dari kenyataan, dan fungsi imformasi verbal dari suatu objek, peristiwa atau manusia, (2) konsep, merupakan pengetahuan tentang seperangkat objek konkrit atau definisi, (3) prosedur, merupakan pengetahuan tentang tindakan demi tindakan yang bersifat linier dalam mencapai suatu 
tujuan, dan (4) prinsip, merupakan yang mengenai hubungan dari dua konsep atau lebih.

Dalam sistem pendidikan di indonesia, PAI merupakan salah satu bidang studi yang harus dipelajari dalam rangka menyelesaikan pendidikan pada tingkat tertentu yang didesain dan diberikan pada pembelajar yang beragam Islam agar mereka dapat mengembangkan dan meningkatkan keberagamaan ( Gafar dan Jamil, 2003).

Dalam garis besar program pembelajaran PAI di sekolah umum, dijelaskan bahwa PAI adalah usaha sadar untuk menyiapkan siswa dalam meyakini, memahami, menghayati, mengamalkan Agama Islam melalui kegiatan bimbingan, pengajaran, atau latihan dengan memperhatikan tuntunan untuk menghormati Agama lain dalam hubungan kerukunan antar beragama dalam masyarakat untuk mewujudkan persatuan Nasional (Muhaimin, 2004)

\section{Hakikat Strategi pembelajaran.}

Gerlach , Elly (1989) menyatakan

bahwa strategi adalah suatu cara yang terpilih untuk menyampaikan tujuan pembelajaran dalam lingkungan pembelajaran tertentu. Definisi yang lain menyebutkan bahwa strategi adalah suatu garis besar haluan untuk bertindak dalam usaha mencapai sasaran yang telah ditentukan (Djamarah , Zain, 2002). Dengan demikian, pengertian strategi dalam pembelajaran adalah suatu prosedur yang digunakan oleh guru dalam proses pembelajaran sebagai sarana untuk mencapai tujuan pembelajaran yang telah ditetapkan.

Suatu set peristiwa itu mungkin dilakukan oleh pengajar sehingga disebut pembelajaran, mungkin juga dilakukan oleh siswa sendiri dengan menggunakan buku, gambar, program televisi atau kombinasi berbagai media, baik oleh pengajar maupun oleh siswa sendiri, kegiatan itu haruslah terencana secara sistematis untuk dapat disebut kegiatan pembelajaran. Dick \& Carey (2005) mengatakan bahwa strategi pembelajaran memuat lima komponen strategi pembelajaran yakni : (1) kegiatan pembelajaran pendahuluan (2) penyampaian informasi (3) partisipasi siswa (4) tes, dan (5) kegiatan lanjutan

Romizowski (1981) berpendapat bahwa strategi pembelajaran merupakan suatu pendekatan menyeluruh yang dapat dibedakan menjadi dua strategi dasar, yaitu ekspositori (penjelasan) dan inquiri/diskoveri (penemuan).
Kedua strategi ini dapat dipandang sebagai dua ujung yang sejalan dalam suatu kontinum strategi, hal ini erat sekali kaitannya dengan pendekatan deduktip dimana strategi ini dimulai dengan penyajian imformasi mengenai prinsip atau kaidah kemudian diikuti dengan tes penguasaan, penerapan, dalam bentuk contoh dan penerapan pada situasi tertentu.

Pengembangan strategi, pembelajaran sebagaimana telah disebutkan terlebih dahulu, mempunyai landasan teori belajar dan pembelajaran, perlunya teori pembelajaran ini menurut Snelbecker (1974) adalah (1) untuk mensistematiskan hasil penelitian agar gejalagejala yang semula tidak diketahui maknanya, dapat dipahami, (2) teori berfungsi menimbulkan hipotesis, dengan demikian dapat memberitahukan kearah mana perhatian harus diberikan dan dimana harus di cari jawaban atas pertanyaan yang timbul, (3) teori dapat digunakan untuk membuat pridiksi, sehingga tidak hanya memberikan jawaban atas pertanyaan yang ada sekarang, melainkan juga menunjukkan hal-hal yang dapat di harapkan, (4) teori dapat digunakan untuk menjelaskan gejala yang dihadapi, atau dengan kata lain melalui teori dapat digunakan untuk menjelaskan gejala yang di hadapi, atau dengan kata lain, melalui teori ini dapat dijelaskan kenapa sesuatu gejala terjadi.

Reigeluth, Merill (1989) mengajukan tiga komponen utama teori pembelajaran, yaitu : Metode, kondisi, dan hasil, yang dimaksud dengan metode pengajaran adalah berbagai macam cara untuk mencapai berbagai macam hasil, dalam berbagai macam kondisi.

\section{Strategi Pembelajaran Berbasis Portofolio}

Portofolio berasal dari bahasa Inggris "portfolio" yang berarti dokumen atau suratsurat Dapat juga diartikan sebagai kumpulan kertas-kertas berharga dari suatu pekerjaan tertentu (Fajar, 2005). Menurut Surapranata dan Hatta (2004) istilah portofolio pertama kali dipergunakan. oleh fotografer dan artis, melalui portofolio para fotografer dapat memperlihatkan prosfektif pekerjaan mereka kepada pelanggan dengan menunjukkan koleksi pekerjaan yang dimiliki.

Istilah portofolio ini selanjutnya diadopsi ke dalam dunia pendidikan dengan makna, kumpulan pekerjaan siswa dengan maksud tertentu dan terpadu yang diseleksi menurut panduan-panduan yang telah ditentukan (Fajar, 2005). 
Hal senada juga dikemukakan oleh Popham sebagaimana dikutip Zamroni (2004) yaitu portofolio berarti kumpulan karya atau tugas-tugas yang dikerjakan peserta didik. Selanjutnya portofolio dijadikan salah satu pendekatan pembelajaran untuk selanjutnya disebut pembelajaran berbasis portofolio dikembangkan oleh Center Civic Education (CCE) yang bermarkas di Calabas Amerika Serikat.

\section{Strategi Pembelajaran Ekspositori \\ Menurut Barry, King}

pembelajaran ekspositori merupakan pembelajaran di mana pengajar menyampaikan informasi secara verbal kepada siswa. Pada pengertian ini, pembelajaran ekspositori merupakan proses pembelajaran yang terpusat kepada pengajar dan pengajar merupakan sumber informasi utama. Meskipun dalam pembelajaran ini digunakan metode selain ceramah dan dibantu dengan alat-alat pelajaran, tetapi penekanannya tetap pada proses penerimaan materi pelajaran yang disampaikan oleh pengajar. Yang terpenting adalah penyajian infomasi terkini dari pengajar dan pengajar rnengawasi aktivitas belajar siswa.

Brady (1985) mendefinisikan pembelajaran ekspositori sebagai pembelajaran yang terpusat kepada pengajar dengan fokus pendekatan melalui ceramah (narration), penjelasan. serta penggunaan latihan dan perbaikan dalam mengkoordinir belajar siswa. Pada pembelajaran ekspositori ini siswa diharapkan siap secara mental dan fisik untuk menerima apa yang diberikan pengajar. Pengajar biasanya melakukan demonstrasi atau meragakan sesuatu untuk menjelaskan materi pelajaran tertentu. Misalnya dalam pelajaran PAI, pengajar biasanya menjelaskan materi pelajaran secara naratif melalui ceramah, kemudian memperjelas materi pelajaran dengan demonstrasi, dan selanjutnya mengadakan tanya jawab terhadap materi yang telah disampaikan. Dalam hubungan ini pengajar memegang kendali seluruh proses pembelajaran dan siswa mengikuti apa yang telah dirancang dan dilakukan oleh pengajar.

Nurhadi (2003) menjelaskan beberapa ciri-ciri pembelajaran ekspositori yaitu (a) siswa meniru informasi secara pasif, (2) prilaku dibangun atas kebiasaan, (3) keterampilan dikembangkan atas dasar latihan, (4) pegetahuan adalah penangkapan terhadap serangkaian fakta, konsep atau hukum yang berada di luar diri siswa, (5) dalam proses pembelajaran bersifat absolut dan final, hal ini disebabkan siswa tidak memperhatikan pengalaman belajar apa yang harus dirangkaikan dalam pikirannya.

Sudjana (2000) menjelaskan ciri-ciri pembelaiaran ekspositori yaitu: pembelajaran yang berpusat pada pengajar, (2) siswa mendengar dan mencatat seperlunya, (3) komunikasi terjadi satu arah. (4) menyamaratakan kemampuan siswa, (5) siswa kurang keberanian bertanya.

\section{Hakikat Kemandirian}

Kemandirian merupakan suatu sikap individu yang diperoleh secara kumulatif selama perkembangan, dimana individu akan terus belajar untuk bersikap mandiri dalam menghadapi berbagai situasi di lingkungan, sehingga individu pada akhirnya akan mampu berpikir dan bertindak sendiri. Dengan kemandiriannya seseorang dapat memilih jalan hidupnya untuk dapat berkembang dengan lebih mantap. Untuk dapat mandiri seseorang membutuhkan kesempatan, dukungan dan dorongan dari keluarga serta lingkungan di sekitarnya, agar dapat mencapai otonomi atas diri sendiri. Pada saat ini peran orang tua dan respon dari lingkungan sangat diperlukan bagi anak sebagai "penguat" untuk setiap perilaku yang telah dilakukannya. Hal ini sejalan dengan apa yang dikatakan Reber (1985) bahwa: “ kemandirian merupakan suatu sikap otonomi dimana seseorang secara relatif bebas dari pengaruh penilaian, pendapat dan keyakinan orang lain". Dengan otonomi tersebut seorang diharapkan akan lebih bertanggungjawab terhadap dirinya sendiri.

Hampir serupa dengan definisi Bandura yaitu berkaitan dengan kontrol diri dalam belajar, Sehunk, Zimmerman (1998) mendefinisikan self regulated learning sebagai proses belajar yang terjadi karena pengaruh dari pemikiran, perasaan, strategi, dan perilaku sendiri yang berorientasi pada pencapaian tujuan. Menurut Sehunk, Zimmerman (1998) terdapat tiga phase utama dalam siklus self regulated learning yaitu, merancang belajar, memantau kemajuan belajar selama menerapkan rancangan, dan mengevaluasi hasil belajar secara lengkap. Serupa dengan Sehunk , Zimmerman (1998), mengemukakan bahwa self regulated learning merupakan siklus kegiatan kognitif yang rekursif (berulang-ulang) yang memuat kegiatan: Menganalisis tugas, memilih, 
mengadopsi, atau menemukan pendekatan strategi untuk mencapai tujuan tugas, dan memantau hasil dari strategi yang telah dilaksanakan.

Selanjutnya, Sehunk, Zimmerman (1998), merinci kegiatan yang berlangsung pada tiap phase self regulated learning sebagai berikut: (1) pada phase merancang belajar berlangsung kegiatan, menganalisis tugas belajar, menetapkan tujuan belajar, dan merancang strategi belajar, (2) pada phase memantau berlangsung kegiatan mengajukan pertanyaan pada diri sendiri. Apakah strategi yang dilaksanakan sesuai dengan rencana? Apakah saya kembali kepada kebiasaan lama? apakah saya tetap memusatkan diri? dan apakah strategi telah berjalan dengan baik?, (3) phase mengevaluasi, memuat kegiatan memeriksa bagaimana jalannya strategi, apakah strategi telah dilaksanakan dengan baik? (evaluasi proses), hasil belajar apa yang telah dicapai? (evaluasi produk), dan sesuaikah strategi dengan jenis tugas belajar yang dihadapi?,(4) pada pase merefleksi: Pada dasarnya pase ini tidak hanya berlangsung pada pase keempat dalam siklus self regulated learning, namun refleksi berlangsung pada tiap phase selama siklus berjalan.

Definisi lain tentang self direction on learning (SDL) dkemukakan Wongsri, Cantwell, Archer (2002) yaitu sebagai proses belajar di mana individu memiliki rasa tanggung jawab dalam merancang belajarnya, dan menerapkan, serta mengevaluasi proses belajarnya. Definisi di atas menggambarkan karakteristik internal dimana individu mengarahkan dan memusatkan diri pada keinginan belajarnya sendiri, serta mengambil tanggung jawab dalam belajarnya. Wongsri, Cantwell, Archer (2002) mengemukakan bahwa kemampuan sel direction on learning harus dimiliki setiap individu terutama yang mengikuti pendidikan tersier (pendidikan tinggi). Pengertian self direction on learning di mana individu mengatur secara aktif proses belajarnya, merupakan proses internal yang dimiliki dan dilaksanakan oleh individu yang sedang belajar. Kemampuan individu dalam memaksimumkan self-direction on learning bukan merupakan bakat, namun dapat ditingkatkan melalui program belajar yang relevan. Hoban, Sersland, Raine (Wongsri, Cantwell, Archer, 2002) merelasikan istilah SDL dengan istilah self-efficacy yang didefinisikan sebagai pandangan individu terhadap kemampuan dirinya dalam bidang akademik tertentu. Pandangan self efficacy individu berpengaruh terhadap pilihan dan kegiatan yang diikutinya. Keadaan tersebut melukiskan bahwa pada dasarnya individu merupakan peserta aktif dalam belajarnya. Selanjutnya, Hoban, Sersland, Raine (Wongsri, Cantwell, Archer, 2002) mengemukakan bahwa self-efficacy berkaitan dengan self-direction on learning, tujuan berprestasi dalam belajar, atribusi, Self Regulated Learning.

Rumusan masalah yang akan ditelusuri dalam penelitian ini adalah sebagai berikut: (1) Apakah hasil belajar PAI yang dibelajarkan dengan strategi pembelajaran berbasis portopolio lebih tinggi dari pada hasil belajar PAI siswa yang dibelajarkan dengan strategi pembelajaran ekspositori ?; (2) Apakah hasil belajar PAI siswa yang memiliki kemandirian tinggi lebih tinggi dari pada hasil belajar PAI siswa yang memiliki kemandirian rendah; dan (3) Apakah terdapat interaksi antara strategi pembelajaran dan kemandirian terhadap hasil belajar PAI ?

\section{METODE}

Penelitian ini dilaksanakan di SMA Negeri 2 Kabupaten Aceh Tengah. Populasi dalam penelitian adalah seluruh siswa kelas XI yang terdiri dari 7 kelas dengan jumlah siswa seluruhnya adalah 207 siswa, yang tersebar dalam 7 kelas tersebut tidak di kelompokkan atas rangking ujian masuk dan pengelompokkan kelas unggulan tetapi penyebaran siswa ke dalam 7 kelas tersebut dilakukan secara acak saja sewaktu penempatan siswa dalam kelompok kelasnya masing-masing. Penelitian ini dilaksanakan selama rentang waktu 6 kali pertemuan. Tekhnik pengambilan sampel dalam penelitian adalah tekhnik cluster random sampling yaitu sampel diambil dengan tujuan tertentu, dipilih 2 (dua) kelas sebagai sampel yang dikenakan perlakuan melalui pemilihan secara acak, Untuk menentukan jenis perlakuan. pada kelas XI IPA.1, yang terdiri dari kelas A.I dan A.2 sebagai kelas pembelajaran portofolio jumlah siswa sebanyak 55 siswa, untuk kelas pembelajaran ekspositori dilakukan pada kelas XI.IPS yang terdiri dari kelas S.1 dan S.2 dengan jumlah sampel sebanya Metode yang dipergunakan dalam penelitian ini adalah metode quasi-eksperimen. Metode ini dipilih karena kelas yang dipakai untuk perlakuan, baik untuk kelas pembelajaran dengan strategi portofolio maupun kelas pembelajaran dengan 
strategi ekspositori merupakan kelas yang sudah terbentuk sebelumnya dan karakteristik siswa yang dikontrol adalah kemandirian siswa.
Desain penelitian yang digunakan adalah faktorial $2 \times 2$ sebagaimana terlihat pada Tabel 1 berikut:

Tabel 1. Rancangan Penelitian

\begin{tabular}{|c|c|c|}
\hline \multirow{2}{*}{ Kemandirian $(\mathrm{B})$} & \multicolumn{2}{|c|}{ Strategi Pembelajaran (A) } \\
\cline { 2 - 3 } & Portofolio $\left(\mathrm{A}_{1}\right)$ & Ekspositori (A $\left.{ }_{2}\right)$ \\
\hline Tinggi $\left(\mathrm{B}_{1}\right)$ & $\mathrm{A}_{1} \mathrm{~B}_{1}$ & $\mathrm{~A} 2 \quad \mathrm{~B}_{1}$ \\
\hline Rendah $\left(\mathrm{B}_{2}\right)$ & $\mathrm{A}_{1} \mathrm{~B}_{2}$ & $\mathrm{~A} 2 \quad \mathrm{~B} 2$ \\
\hline
\end{tabular}

Keterangan:

A : Strategi pembelajaran

B : Kemandirian

$A_{1} \quad$ : Pembelajaran berbasis portofolio

$\mathrm{A}_{2} \quad$ : Pembelajaran ekspositori

$\mathrm{B}_{1} \quad$ : Kemandirian tinggi

$\mathrm{B}_{2} \quad$ : Kemandirian rendah

$\mathrm{A}_{1} \mathrm{~B}_{1}$ : Hasil belajar siswa yang dibelajarkan dengan pembelajaran berbasis portofolio dan kemandirian tinggi

$\mathrm{A}_{1} \mathrm{~B}_{2}$ : Hasil belajar siswa yang dibelajarkan dengan pembelajaran berbasis portofolio dan kemandirian rendah

$\mathrm{A}_{2} \mathrm{~B}_{1}$ : Hasil belajar siswa yang dibelajarkan dengan pembelajaran ekspositori dan kemandirian tinggi

$\mathrm{A}_{2} \mathrm{~B}_{2}$ : Hasil belajar siswa yang diajar dengan pembelajaran ekspositori dan

kemandirian rendah

\section{Teknik Analisis Data}

Teknik analisis data adalah: (1) analisis deskriptif dan (2) analisis inferensial. Teknik analisis deskriptif dimaksudkan untuk mendeskripsikan data penelitian meliputi mean, median, modus, varians dan simpangan baku lebih lanjut data disajikan dalam bentuk Tabel distribusi frekuensi dan histogram nantinya. Sedangkan teknik analisis inferensial dimaksudkan untuk menguji hipotesis yang dilakukan dengan menggunakan teknik analisis varians (ANAVA) dua jalur. Sebelum hipotesis diuji terlebih dahulu dilakukan uji persyaratan analisis yaitu (1) uji normalitas dengan menggunakan uji Liliefors. Ada beberapa langkah dilakukan dalam uji normalitas data dengan uji Liliefors tunggal, (a) menghitung rata-rata skor sampel, (b) menghitung standar deviasi nilai skor sampel, (c) mengurutkan data terkecil ke terbesar, (c) menentukan besar peluang masing-masing nilai berdasarkan Tabel,(d) menghitung frekwensi kumulatif dari masing-masing nilai, (e) menentukan nilai, (f ) apabila L (hitung) lebih kecil dari L (tabel) maka berasal dari populasi yang berdistribusi normal.

Uji normalitas ini dimaksudkan untuk mengetahui apakah data yang diteliti berdistribusi normal atau tidak, (2) uji homogenitas menggunakan teknik uji Fisher dan uji Bartlett. Pengujian homogenitas dilakukan untuk melihat apakah data yang diperoleh memiliki variasi yang homogen atau tidak.

\section{Hipotesis Penelitian.}

Hipotesis statistik dapat dinyatakan sebagai berikut:

a. Hipotesis pertama: Ho $: \mu$. SPBP $=\mu$. SPE

$\mathrm{Ha}: \mu$. SPBP $>\mu$. $\mathrm{SPE}_{\mathrm{PE}}$

b. Hipotesis kedua : Ho : $\mu . \mathrm{KT}=\mu . \mathrm{KR}$

$\mathrm{Ha}: \mu . \mathrm{K}_{\mathrm{T}}>\mu \mathrm{K}_{\mathrm{R}}$

c. Hipotesis ketiga : Ho : $\mathrm{SXK}=0$

$\mathrm{Ha}: \mathrm{SXK} \neq 0$

Keterangan :

$\mathrm{S} \quad$ : Strategi pembelajaran

K : Kemandirian

SPBP : Strategi pembelajaran berbasis portofoplio

SPE : Strategi pembelajaran berbasis ekspositori

KT : Kemandirian tinggi

KR : Kemandirian rendah

$\mu \quad$ : Rata-rata hasil belajar

\section{HASIL DAN PEMBAHASAN \\ Hasil}

Berdasarkan data skor tes hasil belajar PAI siswa, langkah berikutnya adalah menghitung total skor dan rata-rata skor tiap kelompok perlakuan menurut Tabel ANAVA, yang selanjutnya dapat digunakan sebagai dasar keputusan statistik untuk pengujian hipotesis, seperti pada Tabel 2. sebagai berikut: 
Tabel 2. Ringkasan Hasil Statistik Deskriptif Data Perhitungan

\begin{tabular}{|c|c|c|c|c|c|c|c|}
\hline \multirow{2}{*}{\multicolumn{2}{|c|}{ Variabel }} & \multicolumn{4}{|c|}{ Strategi Pembelajaran } & \multirow{2}{*}{\multicolumn{2}{|c|}{ Total }} \\
\hline & & & ortofolio & & spositori & & \\
\hline \multirow{10}{*}{ 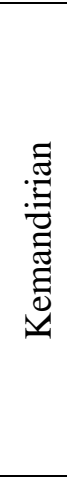 } & & $\mathrm{n}$ & $=17$ & & $=16$ & $\mathrm{n}$ & $=33$ \\
\hline & & $\bar{X}$ & $=36,15$ & $\bar{X}$ & $=32,13$ & $\bar{X}$ & $=34,20$ \\
\hline & .0 & $\sum X$ & $=612$ & $\sum X$ & $=510$ & $\sum X$ & $=1122$ \\
\hline & $F$ & $\bar{\sum} \mathrm{X}^{2}$ & $=22122$ & $\sum X^{2}$ & $=16328$ & $\sum X^{2}$ & $=38450$ \\
\hline & & $\mathrm{S}$ & $=2,57$ & $\mathrm{~S}$ & $=2,22$ & $\mathrm{~S}$ & $=1,80$ \\
\hline & & $\mathrm{n}$ & $=13$ & $\mathrm{n}$ & $=14$ & $\mathrm{n}$ & $=27$ \\
\hline & 족 & $\bar{X}$ & $=31,19$ & $\bar{X}$ & $=32,93$ & $\bar{X}$ & $=32,20$ \\
\hline & 苟 & $\sum \mathrm{X}$ & $=407$ & $\sum \mathrm{X}$ & $=455$ & $\sum X$ & $=862$ \\
\hline & & $\sum \mathrm{X}^{2}$ & $=12797$ & $\sum \mathrm{X}^{2}$ & $=14865$ & $\sum X^{2}$ & $=27662$ \\
\hline & & $\bar{S}$ & $=2,43$ & $\bar{S}$ & $=2,38$ & $\bar{S}$ & $=2,27$ \\
\hline \multirow{5}{*}{\multicolumn{2}{|c|}{ Total }} & $\mathrm{n}$ & $=30$ & $\mathrm{n}$ & $=30$ & $\mathrm{n}$ & $=60$ \\
\hline & & $\bar{X}$ & $=34,00$ & $\bar{X}$ & $=32,50$ & $\bar{X}$ & $=33,25$ \\
\hline & & $\sum \mathrm{X}$ & $=1019$ & $\sum \mathrm{X}$ & $=965$ & $\sum X$ & $=1984$ \\
\hline & & $\bar{\sum} \mathrm{X}^{2}$ & $=34919$ & $\bar{\sum} \mathrm{X}^{2}$ & $=31193$ & $\bar{\sum} X^{2}$ & $=66112$ \\
\hline & & $\bar{S}$ & $=3,46$ & $\bar{S}$ & $=2,29$ & $\bar{S}$ & $=2,87$ \\
\hline
\end{tabular}

\section{Pengujian Hipotesis}

Secara keseluruhan hasil Anava untuk pengujian hipotesis dapat dilihat pada Tabel 3 berikut:

Tabel 3. Rangkuman Hasil Anava Secara Keseluruhan Terhadap Hasil belajar Pendidikan Agama Islam

\begin{tabular}{|l|c|c|c|c|c|}
\hline \multicolumn{1}{|c|}{ Sumber variasi } & $\mathrm{dk}$ & $\mathrm{JK}$ & $\mathrm{RJK}$ & $\mathrm{F}_{\text {Hitung }}$ & $\begin{array}{c}\mathrm{F}_{\text {Tabel(1.56) }} \\
(\alpha=0.05)\end{array}$ \\
\hline Strategi Pembelajaran (A) & 1 & 63,88 & 63,88 & 12,16 & \\
Kemandirian (B) & 1 & 48,60 & 48,60 & 9,25 & 3,96 \\
Interaksi (A X B ) & 1 & 101,23 & 101,23 & 19,28 & \\
Galat & 56 & 294,019 & 5,25 & & \\
\hline Total & 60 & & & & \\
\hline
\end{tabular}

Perbedaan Hasil belajar PAI Antara Siswa Yang Diajar dengan Strategi Pembelajaran Berbasis Portofolio dan Strategi Pembelajaran Ekspositori

$\mu$ Adapun hipotesis statistik yang diuji adalah : Ho : $\mu \mathrm{A} 1=\mu \mathrm{A} 2$

$\mathrm{Ha}: \mu \mathrm{A} 1>\mu \mathrm{A} 2$

Dari hasil analisis data diperoleh ratarata nilai Strategi Pembelajaran Berbasis Portofolio adalah 34,00 dan rata-rata nilai Strategi Pembelajaran Ekspositori adalah 32,50. Berdasarkan hasil pengujian hipotesis pada Tabel $24 \mathrm{di}$ atas, maka diperoleh hasil perhitungan data strategi pembelajaran, dimana $\mathrm{F}_{\text {hitung }}=12,16$ sementara nilai kritik $\mathrm{F}_{\text {Tabel }}$ dengan $\mathrm{dk}=(1,56)$ dan $\alpha=0,05$ adalah sebesar 3,96 Hasil ini menunjukkan bahwa $\mathrm{F}_{\text {hitung }}=$ 12,16 $>\mathrm{F}_{\text {Tabel }}=3,99$ sehingga Hipotesis Nol (Ho) ditolak dan (Ha) diterima, dengan demikian hipotesis penelitian yang menyatakan bahwa hasil belajar PAI siswa yang dibelajarkan dengan strategi pembelajaran berbasis portofolio lebih tinggi dari pada siswa yang diajarkan dengan strategi pembelajaran ekspositori teruji kebenarannya.

\section{Perbedaan Hasil belajar PAI Antara Siswa Yang Memiliki Kemandirian tinggi dan Kemandirian rendah}

Adapun hipotesis statistik yang diuji adalah :

Ho $: \mu \mathrm{B} 1=\mu \mathrm{B} 2$

$\mathrm{Ha}: \mu \mathrm{B} 1>\mu \mathrm{B} 2$

Dari hasil analisis data diperoleh rata-rata nilai kemandirian tinggi adalah 34,20 dan ratarata nilai kemandirian rendah adalah 32,20. Berdasarkan hasil pengujian hipotesis pada Tabel 24 di atas diperoleh hasil perhitungan data kemandirian, dimana $F_{\text {hitung }}=9,25$ dan nilai 
kritik $\mathrm{F}_{\text {Tabel }}$ dengan $\mathrm{dk}=(1,56)$ dan $\alpha=0,05$ adalah 3,96. Hasil ini menunjukkan bahwa $\mathrm{F}_{\text {hitung }}=9,25>\mathrm{F}_{\text {Tabel. }}=3,96$ sehingga Hipotesis Nol (Ho) ditolak, dengan demikian hipotesis penelitian yang menyatakan bahwa siswa yang memiliki kemandirian rendah memperoleh hasil belajar PAI yang lebih tinggi dari pada Siswa yang memiliki kemandirian rendah teruji kebenarannya.

Interaksi Antara Strategi Pembelajara dan Kemandirian Siswa Terhadap Hasil belajar PAI

Adapun hipotesis statistik yang diuji adalah :

Ho : $\mathrm{A}><\mathrm{B}=0$

$\mathrm{Ha}: \mathrm{A}><\mathrm{B} \neq 0$

Dari hasil analisis data rata-rata nilai strategi pembelajaran berbasis portofolio yang memiliki kemandirian tinggi adalah 36,15 . Rata-rata nilai strategi pembelajaran berbasis portofolio yang memiliki kemandirian rendah adalah 31,19. Rata-rata nilai strategi pembelaran ekspositori yang memiliki kemandirian tinggi adalah 32,13. Rata-rata nilai strategi pembelajaran ekspositori yang memiliki kemandirian rendah adalah 32,93.

Berdasarkan hasil pengujian hipotesis di atas diperoleh perhitungan interaksi strategi pembelajaran dengan motivasi Siswa, dimana $\mathrm{F}_{\text {hitung }}=19,28$ dan nilai kritik $\mathrm{F}_{\text {Tabel }}$ dengan $\mathrm{dk}=$ $(1,56)$ dan $\alpha=0.05 \%$ adalah 3,96 . Hasil ini menunjukkan bahwa $F_{\text {hitung }}=19,28>F_{\text {Tabel. }}=$ 3,99 sehingga Hipotesis Nol (Ho) ditolak, dengan demikian hipotesis penelitian yang menyatakan bahwa terdapat interaksi antara strategi pembelajaran dan motivasi Siswa dalam memberikan pengaruh terhadap hasil belajar Pendidikan Agama Islam teruji kebenarannya.

Karena ada interaksi antara strategi pembelajaran dan kemandirian dalam mempengaruhi hasil belajar PAI, maka perlu dilakukan uji lanjutan (post hoc test), untuk mengetahui rata-rata hasil belajar sampel mana yang berbeda. Untuk melihat bentuk interaksi antara strategi pembelajaran dan motivasi dalam mempengaruhi hasil belajar PAI, dilakukan uji lanjut dengan menggunakan uji Scheffe. Ringkasan hasil uji Scheffe dapat dilihat pada Tabel 4. berikut:

Tabel 4. Ringkasan Hasil Perhitungan Uji Scheffe

\begin{tabular}{|c|c|c|c|}
\hline $\begin{array}{c}\text { Skor kelompok } \\
\text { yang dibandingkan }\end{array}$ & $F_{\text {Hitung }}$ & $F_{\text {Tabel }(3,56)}$ & \multirow{2}{*}{ Ket. } \\
\cline { 3 - 3 } & & $\alpha=0,05$ & \\
\hline$\mu$ A1B1 dengan $\mu$ A1B2 & 5,86 & 2.75 & Signifikan \\
\hline$\mu$ A1B1 dengan $\mu$ A2B1 & 5,03 & 2.75 & Signifikan \\
\hline$\mu$ A1B1 dengan $\mu$ A2B2 & 3,89 & 2.75 & Signifikan \\
\hline$\mu$ A2B1 dengan $\mu$ A2B2 & 0,95 & 2.75 & Tidak Signifikan \\
\hline$\mu \mathrm{A} 2 \mathrm{~B} 1$ dengan $\mu \mathrm{A} 1 \mathrm{~B} 2$ & 1,09 & 2.75 & Tidak Signifikan \\
\hline$\mu \mathrm{A} 1 \mathrm{~B} 2$ dengan $\mu \mathrm{A} 2 \mathrm{~B} 2$ & 1,96 & 2.75 & Tidak Signifikan \\
\hline
\end{tabular}

Kriteria penerimaan jika : $\mathrm{F}_{\text {hitung }}>\mathrm{F}_{\text {Tabel, }}$ maka teruji secara signifikan. Berdasarkan hasil uji Scheffe di atas dapat dilihat bahwa terdapat 6 (enam) pasang hipotesis statistik, yakni :

a. Dari hasil perhitungan dengan menggunakan uji Scheffe pada Tabel di atas menunjukkan bahwa $F_{\text {hitung }}=5,86>\mathrm{F}_{\text {Tabel }}=2,75$ sehingga memberikan keputusan menolak Ho. Dengan demikian, hipotesis penelitian yang menyatakan bahwa hasil belajar PAI siswa jika diajar menggunakan strategi pembelajaran berbasis portofolio lebih tinggi dibandingkan dengan strategi pembelajaran portofolio untuk siswa yang memiliki kemandirian rendah teruji kebenarannya.

b. Dari hasil perhitungan dengan menggunakan uji Scheffe pada Tabel di atas menunjukkan $\mathrm{F}_{\text {hitung }}=5,03>\mathrm{F}_{\text {Tabel }}=2,75$ sehingga memberikan keputusan menolak Ho. Dengan demikian, hipotesis penelitian yang menyatakan bahwa hasil belajar PAI siswa yang memiliki kemandirian tinggi jika diajar dengan strategi pembelajaran berbasis portofolio lebih tinggi daripada hasil belajar siswa yang memiliki kemandirian tinggi jika diajar dengan strategi pembelajaran ekspositori teruji kebenarannya.

c. Dari hasil perhitungan dengan menggunakan uji Scheffe pada Tabel di atas menunjukkan $\mathrm{F}_{\text {hitung }}=3,89>\mathrm{F}_{\text {Tabel }}=2,75$ sehingga memberikan keputusan menolak Ho. Dengan demikian, hipotesis penelitian yang menyatakan bahwa Hasil belajar PAI siswa dengan kemandirian tinggi jika diajar menggunakan strategi pembelajaran berbasis portofolio lebih tinggi dibandingkan dengan 
siswa yang memiliki kemandirian rendah jika diajar menggunakan strategi pembelajaran ekspositori teruji kebenarannya.

d. Dari hasil perhitungan dengan menggunakan uji Scheffe pada Tabel di atas menunjukkan $\mathrm{F}_{\text {hitung }}=0,95<\mathrm{F}_{\text {Tabel }}=2,75$ sehingga memberikan keputusan menerima Ho. Dengan demikian tidak terdapat perbedaan antara hasil belajar siswa yang diajar dengan strategi pembelajaran berbasis portofolio yang memiliki kemandirian tinggi dengan hasil belajar siswa yang diajar dengan strategi pembelajaran ekspositori yang memiliki kemandirian rendah.

e. Dari hasil perhitungan dengan menggunakan uji Scheffe pada Tabel di atas menunjukkan $\mathrm{F}_{\text {hitung }}=1,09<\mathrm{F}_{\text {Tabel }}=2,75$ sehingga memberikan keputusan menerima Ho. Dengan demikian tidak terdapat perbedaan antara hasil belajar Siswa yang diajar dengan strategi pembelajaran berbis portofolio yang memiliki kemandirian rendah dengan hasil belajar siswa yang diajar dengan strategi pembelajaran ekspositori yang memiliki kemandirian tinggi.

f Dari hasil perhitungan dengan menggunakan uji Scheffe pada Tabel di atas menunjukkan $\mathrm{F}_{\text {hitung }}=1,96>\mathrm{F}_{\text {Tabel }}=2,75$ sehingga memberikan keputusan menerima Ho. Dengan demikian tidak terdapat perbedaan antara hasil belajar siswa yang diajar dengan strategi pembelajaran berbasis portofolio yang memiliki kemandirian rendah dengan hasil belajar siswa yang diajar dengan strategi pembelajaran ekspositori yang memiliki kemandirian rendah.

Selanjutnya adanya interaksi antara variabel strategi pembelajaran berbasis portofolio dan strategi pembelajaran ekspositori terhadap kemandirian, maka perlu diberikan Gambaran grafik estimasi yang menunjukkan adanya interaksi tersebut. Grafik interaksi ditunjukkan oleh Gambar 1. berikut:

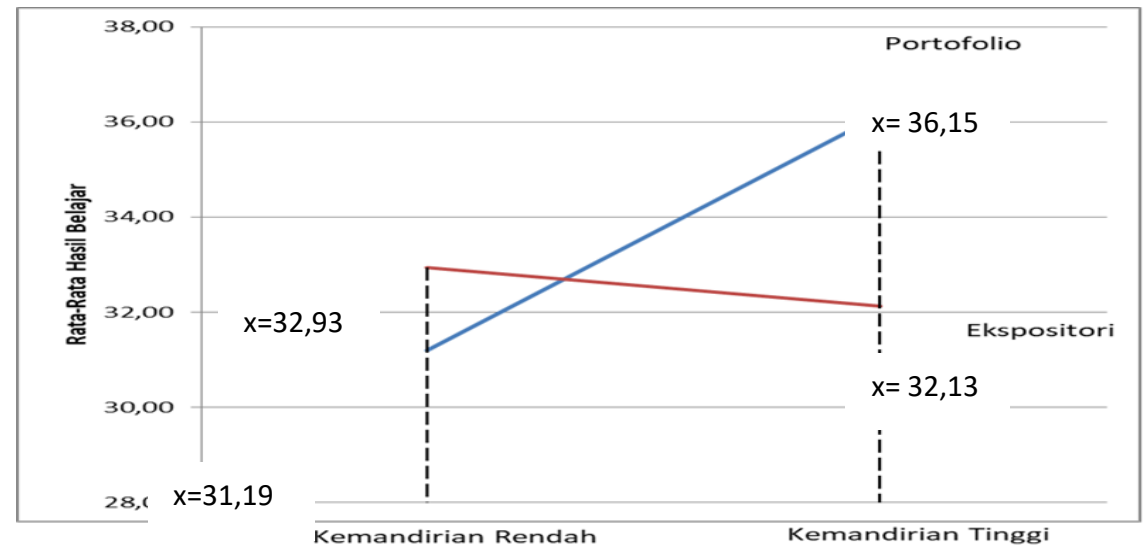

Gambar1. Model Interaksi Antara Strategi Pembelajaran dan Kemandirian Terhadap Hasil belajar PAI

\section{Pembahasan}

Strategi pembelajaran berbasis portopolio berdasarkan teori bahwa(1) Preparasi, guru menyiapkan bahan/materi pembelajaran, (2). Apersepsi diperlukan untuk penyegaran, (3). Presentasi (penyajian) materi pembelajaran, (4). Resitasi, pengulangan pada bagian yang menjadi kata kunci kompetensi pembelajaran, media pembelajaran yang di gunakan untuk alat bantu dalam rangka memperjelas materi pembelajaran yang disampaikan, prosedurnya yang terdiri dari kegiatan awal,motivasi dan melakukan apersepsi, strategi pembelajaran portofolio menekankan pada pembelajaran siswa menemukan sendiri apa yang dipelajarinya, bukan hanya mengetahui dari seorang guru saja, ini tidak terjadi dalam pembelajaran ekspositori. Prilaku hasil belajar yang diperoleh melalui pembelajaran berbasis portofolio lebih bermakna bagi siswa disebabkan karena informasi-informasi belajar yang terjadi dalam pembelajaran hal ini bersumber dari keaktifan siswa karena pembelajaran, langsung dan alamiah dalam bentuk kegiatan atau proses "terlibat aktif" yang dilakukan siswa.

Siswa yang dibelajarkan dengan pembelajaran berbasis portofolio memberikan 
hasil belajar yang lebih baik karena adanya kaitan materi pelajaran dengan lingkungan siswa yang digali dan ide-ide dari siswa dan guru sebagai fasilitator dalam mencapai tujuan pembelajaran yang diinginkan. Bila dibandingkan dengan pembelajaran ekspositori kegiatan pembelajaran satu persatu dan konsep disampaikan oleh guru .

Berdasarkan data yang diperoleh, menunjukkan bahwa hasil belajar rata-rata bagi siswa yang diajar dengan strategi pembelajaran berbasis portofolio $(34,00)$ lebih baik dari hasil belajar siswa yang diajar dengan menggunakan ekspositori $(32,50)$. Dari hasil perbandingan rata-rata yang diperoleh memberikan arti bahwa hasil belajar siswa yang diajar dengan pembelajaran berbasis portofolio lebih baik dari hasil belajar siswa yang diajar dengan menggunakan Ekspositori.

Berdasarkan kenyataan ini menyebabkan pembelajaran dengan menggunakan ekspositori kurang menghasilkan perhatian yang maksimal bagi siswa, oleh karena mereka bosan dan merasa terlalu monoton, akibatnya adalah siswa kurang memperoleh informasi yang tertuang dalam Ekspositori.

Selanjutnya dengan pembelajaran menggunakan ekspositori, siswa kurang berkomunikasi dengan teman-temannya, karena masing-masing hanya mengandalkan kemampuan sendiri untuk memahami materi sajian guru, sedangkan dengan pembelajaran berbasis portofolio, siswa lebih leluasa mengkomunikasikan temuan yang diperoleh dengan teman kelompoknya pada saat melakukan kegiatan belajar. Komunikasi antara teman dan guru memberikan solusi yang cepat bagi siswa untuk melengkapi ketidak tahuannya tentang bahan yang dipelajarai. Hasil penelitian ini mendukung temuan penelitian Rully (2008) tentang Pengaruh Model Pembelajaran Berbasis Portofolio dan Kemampuan Awal Terhadap Hasil Belajar Pendidikan Kewarganegaran Siswa Kelas 1 SMA Negeri di Kabupaten Gayo Luwes, menemukan bahwa penerapan model pembelajaran berbasis portofolio memberikan pengaruh terhadap hasil belajar pendidikan kewarganegaran siswa dibandingkan model pembelajaran konvensional.

Berdasarkan temuan yang dikemukakan bahwa secara umum perbedaan antara pembelajaran berbasis portofolio dengan pembelajaran mengunakan ekspositori terletak dalam berbagai aspek antara lain, bahwa pembelajaran menggunakan ekspositori menunjukkan ciri pembelajaran yang mengharapkan guru menyediakan materi bahan ajar sebagai sumber informasi, sedangkan pada pembelajaran berbasis portofolio siswa akan menemukan sendiri lebih banyak informasi melalui aktivitas bersama di bawah pengawasan guru. Pembelajaran dengan menggunakan ekspositori dan pembelajaran berbasis portofolio dipandang dapat efektif dalam penguasaan mata pelajaran PAI dan mampu membina siswa ke arah pemikiran saintifik, hanya saja dengan menggunakan Ekspositori akan membatasi ruang lingkup penguasaan siswa terhadap materi yang dipelajari, sedangkan dengan berbasis portopolio akan memberikan keluwesan bagi siswa untuk mengkaji materi lain yang terkait dengan usaha siswa untuk meningkatkan kemampuan mereka.

Tingkat kemandirian belajar merupakan faktor yang sangat penting dalam kehidupan manusia, terutama dalam hal meningkatkan dan berbuat lebih baik untuk mencapai kesuksesan dalam kehidupannya. Dengan adanya kemandirian dalam diri seseorang akan semakin memudahkan dirinya untuk memecahkan dan menyelesaikan masalah baik dalam lingkungan sekolah maupun dalam lingkungan masyarakat. Tingkat kemandirian juga dapat membantu siswa dalam memecahkan masalah-masalah yang dihadapi di setiap mata pelajaran yang ada di sekolah. Oleh karena itu diperlukan kemampuan dari seorang guru untuk menciptakan suasana agar siswa lebih giat, bersemangat untuk lebih mengetahui dan memahami materi pelajaran, senang untuk bertanya, berani untuk mengajukan pendapat dan mau melakukan percobaan yang menuntut adanya pengalaman baru.

Siswa yang mempunyai tingkat kemandirain tinggi lebih mampu memanfaatkan sumber belajar yang ada secara maksimal untuk mempercepat proses pemecahan masalah belajarnya, yang pada gilirannya kemandirian siswa juga akan memiliki pengaruh yang berarti terhadap peningkatan prestasi belajar siswa. Oleh karena itu apabila siswa memiliki tingkat kemandirian tinggi maka siswa itu diduga akan mempunyai prestasi yang lebih baik dalam belajar. Sedangkan siswa yang mempunyai tingkat kemandirian rendah kurang mampu memanfaatkan sumber belajar yang ada dan tidak mampu untuk bekerja secara lebih efektif dan efisien untuk memecahkan permasalahan, sehingga dengan tingkat kemandirian siswa 
yang rendah juga akan mempengaruhi peningkatan prestasi belajar siswa yang rendah. Oleh karena itu apabila siswa memiliki tingkat kemandirian rendah maka siswa itu diduga akan mempunyai prestasi yang rendah.

Siswa yang memiliki tingkat kemandirian tinggi yang cenderung akan memberikan dampak untuk berinisiatif, kemauan belajar yang tinggi serta kesiapan belajar yang dapat di atasi sendiri tanpa ketergantungan dengan orang lain, sehingga diduga akan lebih efektif diajar dengan menggunakan strategi pembelajaran berbasis portofolio untuk meningkatkan hasil belajarnya. Sebab dengan strategi ini proses pembelajaran sangat berpusat pada kemandirian siswa dalam menemukan jawaban dari suatu persoalan dalam pembelajaran dan menekankan langkah langkah berpikir yang dimulai dengan mengamati sampai kepada mendeskripsikan hasil perolehannya untuk mencapai penyelesaian serta menuntut keaktifan dan kemandirian siswa dalam mencari sumbersumber belajar yang dijadikan acuan dalam menyelesaikan materi ajar. Sebaliknya, jika siswa memiliki tingkat kemandirian tinggi diajar dengan strategi ekspositori diduga prestasinya akan lebih rendah, sebab metode didominasi oleh guru, sehingga siwa yang memiliki kemampuan berpikir untuk mengetahui sebab - sebab dari suatu persoalan, dengan kemampuan yang ada pada dirinya tidak terealisasikan dengan baik, sehingga timbul rasa kejenuhan dalam belajar yang mengakibatkan hasil belajarnya rendah.

Sementara siswa yang memiliki tingkat kemandirian rendah, dan siswa ini memiliki pola pikir yang teratur dan spesifik, suka menyelesaikan suatu permasalahan secara tahap demi tahap dan memerlukan prosedur lengkap yang diberikan oleh orang lain untuk menemukan suatu konsep baru dalam belajar bila diajar dengan menggunakan strategi pembelajaran berbasis portofolio diduga kurang meningkatkan hasil belajarnya. Sebab strategi ini lebih berpusat pada diri siswa, guru hanya sebagai motivator atau pembimbing. Dengan demikian, siswa yang memiliki tingkat kemandirian rendah kurang mampu menyelesaikan persoalan - persoalan dengan baik. Bagi siswa yang memiliki tingkat kemandirian rendah dalam proses pembelajaran, strategi pembelajaran ekspositori akan lebih efekif digunakan untuk meningkatkan hasil belajarnya. Sebab langkah - langkah yang digunakan dalam strategi pemebelajaran ekspositori sesuai dengan karakteristik siswa yang memiliki tingkat kemandirian rendah karena siswa tinggal merencanakan apa yang disajikan oleh gurunya, kemudian menghafal di rumah jika diadakan ulangan tes oleh guru sehingga dimungkinkan hasil belajarnya akan lebih baik.

\section{PENUTUP}

Berdasarkan hasil penelitian dan pembahasan dapat dikemukakan kesimpulan sebagai berikut :

1. Strategi pembelajaran berbasis portofolio dan strategi pembelajaran ekspositori berpengaruh signifikan terhadap hasil belajar pendidikan agama islam siswa dimana hasil belajar PAI siswa yang dibelajarkan dengan strategi pembelajaran berbasis portofolio lebih tinggi dibandingkan siswa yang dibelajarkan dengan strategi pembelajaran ekspositori.

2. Tingkat kemandirian belajar berpengaruh signifikan terhadap hasil belajar PAI siswa dimana hasil belajar siswa yang memiliki tingkat kemandirian tinggi lebih tinggi dibandingkan siswa yang memiliki tingkat kemandirian rendah.

3. Terdapat interaksi antara strategi pembelajaran dan kemandirian dalam mempengaruhi hasil belajar PAI. Siswa dengan tingkat kemandirian tinggi akan memperoleh hasil belajar yang lebih tinggi jika dibelajarkan dengan strategi pembelajaran berbasis portofolio. Sebaliknya siswa yang memiliki tingkat kemandirian rendah akan memperoleh hasil belajar yang lebih tinggi jika dibelajarkan dengan strategi pembelajaran ekspositori.

\section{DAFTAR PUSTAKA}

Barry dan King. (1994) http:/www. Pembelajaran ekspositori .co/) yang dikutip pada hari Selasa, tanggal 8 Desember 2018).

Brady. (1985) http:/www. Pembelajaran ekspositori. jhargis.co/) yang dikutip pada hari Selasa, tanggal 8 Desember 2018).

Dick and Carey (2005) The Sistemati Design of Instruction, Illion : Scott Forresman CO.

Djamarah dan Zain, (2002) Strategi Belajar Mengajar, Jakarta :Rineka Cipta 
Djamarah. (1994) Strategi Belajar Mengajar, Cet.3, Rineka Cipta Jakarta ,Jakarta :Rineka Cipta

Fajar, (2005) Pembelajaran Fortopolio Jakarta : Rineka Cipta

Gafar, A.,Irpan dan Jamil, Muhammad, B.M. (2003). Re-Formulasi Rancangan Pembelajaran Pendidikan Agama Islam: Jakarta: Nur Insani.

Gagne , (1977), The Conditioning of Learning, Design. New York : Holt Rinehart, Wintson

Gagne dan Briggs, (1979) Principles of instructional, Design. New York : Holt Rinehart, Wintson

Gerlach dan Elly , (1989) http:/www.jhargis.co/) yang dikutip pada hari Sabtu, tanggal 11 Desember 2011).

Nurhadi , (2003), Pendekatan Konstekstual Dalam Pembelajaran, Jakarta : Rineka Cipta

Reber, S.A., Reber, S.E. (2010). Kamus Psikologi. Yogyakarta: Pustaka Pelajar.

Reigeluth dan Merill, (1989) Instructional Design Theories and Models Design. New York : Holt Rinehart, Wintson

Reigeluth, (1983) Instructional theorios in action Design. New York : Holt Rinehart, Wintson

Romizowski, (1981) Designing Instructional System. New York : Nichol Publishing Company.

Rully Medan, (2008) Pengaruh Model pembelajaran berbasis portofolio dan kemampuan awal terhadap hasil belajar pendidikan kewarganegaraan siswa kelas I SMA Negeri di Kabupaten Gayo Lues, Tesis, Program Pasca Sarjana Universitas Negeri Medan

Sardiman A.M, (2005) Interaksi dan Motivasi Belajar Mengajar. Jakarta: Rajawali Pres

Sehunk, Zimmerman, (1998) http:/www. Self Regulated Learning. jhargis.co/) yang dikutip pada hari Selasa, tanggal 9 September 2011).

Snellbecker, (1974) Learning Theory, Instructional Theory, and Psychoeducational, Design, New York ;Mc Graw Hill

Sudjana, (2000) Metode Statistik . Bandung :Tarsito

Sudjana, (1989) Prosedur Penelitian. Jakarta :Rineka Cipta

Wardiman , (2001) Strategi Belajar Mengajar, Jakarta : Rineka Cipta
Wongsri, N., Cantwell, R.H, Archer J. (2002). The Validation of Measures of SelfEfficacy, Motivation and self-Regulated Learning among Thai tertiary Students. Paper presented at the Annual Conference of the Australian Association for Research in Education, Brisbane, December 2002

Zamroni. (2003). Paradigma Pendidikan Masa Depan. Yogyakarta: Bigraf Publishing.

Zimmerman, B. J. (1998). Theories of selfregulated learning and academic achievement: An overview and analysis. Mahwah, NJ: Lawrence Erlbaum Associates, Inc. 